$$
\text { DF. } 0425=1
$$

\title{
OUTLINE TEST PLAN FOR TEST SERIES I
}

By

NCB (IEA Grimethorpe) LTD.

February 1981

Work Performed Under International Agreement No.: ET10393

For

U. S. Department of Energy

Office of Fossil Energy

Morgantown Energy Technology Center

Morgantown, West Virginia

By

NCB (IEA Grimethorpe) LTD.

Grimethorpe,

Barnsley,

South Yorkshire, England

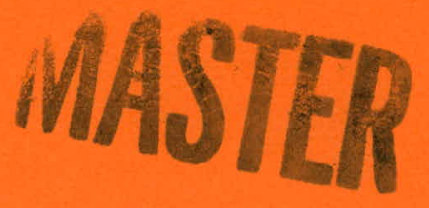

Technical Information Center

Office of Scientific and Technical Information

United States Department of Energy 


\section{DISCLAIMER}

This report was prepared as an account of work sponsored by an agency of the United States Government. Neither the United States Government nor any agency Thereof, nor any of their employees, makes any warranty, express or implied, or assumes any legal liability or responsibility for the accuracy, completeness, or usefulness of any information, apparatus, product, or process disclosed, or represents that its use would not infringe privately owned rights. Reference herein to any specific commercial product, process, or service by trade name, trademark, manufacturer, or otherwise does not necessarily constitute or imply its endorsement, recommendation, or favoring by the United States Government or any agency thereof. The views and opinions of authors expressed herein do not necessarily state or reflect those of the United States Government or any agency thereof. 


\section{DISCLAIMER}

Portions of this document may be illegible in electronic image products. Images are produced from the best available original document. 


\title{
DISCLAIMER
}

\begin{abstract}
This report was prepared as an account of work sponsored by an agency of the United States Government. Neither the United States Government nor any agency thereof, nor any of their employees, makes any warranty, express or implied, or assumes any legal liability or responsibility for the accuracy, completeness, or usefulness of any information, apparatus, product, or process disclosed, or represents that its use would not infringe privately owned rights. Reference herein to any specific commercial product, process, or service by trade name, trademark, manufacturer, or otherwise does not necessarily constitute or imply its endorsement, recommendation, or favoring by the United States Government or any agency thereof. The views and opinions of authors expressed herein do not necessarily state or reflect those of the United States Government or any agency therenf.
\end{abstract}

This report has been reproduced directly from the best available copy.

Available from the National Technical Information Service, U. S. Department of Commerce, Springfield, Virginia 22161.

Price: Printed Copy A02

Microfiche A01

Codes are used for pricing all publications. The code is determined by the number of pages in the publication. Information pertaining to the pricing codes can be found in the current issues of the following publications, which are generally available in most libraries: Energy Research Abstracts (ERA); Government Reports Announcements and Index (GRA and I); Scientific and Technical Abstract Reports (STAR); and publication NTIS-PR-360 available from NTIS at the above address. 


\title{
OUTLINE TEST PLAN FOR TEST SERIES I
}

\author{
By \\ NCB (IEA Grimethorpe) LTD.
}

\author{
February 1981
}

Work Performed Under International Agreement No.: ET10393

For

U. S. Department of Energy

Office of Fossil Energy

Morgantown Energy Technology Center

Morgantown. West Virginia 26505

By

NCB (IEA Grimethorpe) LTD.

Grimethorpe,

Barnsley,

South Yorkshire, England S72 7AB

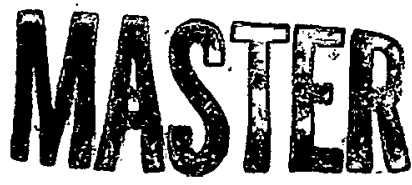




\section{THIS PAGE \\ WAS INTENTIONALLY LEFT BLANK}


This report, which was originally issued to the Project's Technical Committee during February, 1981 as a draft Document No. GEF/TC/P/81/5, is now issued as a Technology Transfer Report.

It must be appreciated that the report was prepared before the commencement of Test series $I$, and is therefore designed to show what was planned for the tests.

\section{SUMMARY}

The overall technical objectives for the Phase 1 programme were presented in a draft document "Phase 1 Research Programme: Baseline and Modified Option Cases", produced in May 1979 and discussed at subsequent Technical Committee Meetings. The technical objectives for Test Series 1 presented in this document have developed from those outlined in the May 79 Baseline; all the changes from the earlier outline are recorded. The data collection systems expected to be used are also presented. It is planned to carry out experiments to meet the objectives in three sub-series each along a different "good fluidisation" line determined at high, medium and low velocities. The high velocity sub-series has four runs including the original design conditions for Tube Bank ' $A$ '. The medium velocity sub-series has seven runs and involves operating Tube Bank ' $A$ ' at what are opined to be its optimum operating conditions. The low velocity sub-series has six runs including the CURL Link Test operating conditions. The range of conditions covered in the seventeen runs is as follows:-

$\begin{array}{lll}\text { Air mass rates, } \mathrm{kg} / \mathrm{s} & \ldots & 14 \text { to } 31 \\ \text { Mean fluidising velocities, } \mathrm{m} / \mathrm{s} & \ldots & 1.6 \text { to } 2.7 \\ \text { Bed heights, m } & \ldots & 1.7 \text { to } 3.5 \\ \text { Pressures, bar abs } & \ldots & 6 \text { and } 10 \\ \text { Mean bed temperatures, }{ }^{\circ} \mathrm{C} & \ldots & 800 \text { to } 900^{\circ} \mathrm{C} \\ \text { Excess air levels, } 8 & \ldots & 35 \text { to } 70 \\ \text { Ca/s molar ratio } & \cdots & 1.8 \text { and } 2.6 \\ \text { Fuel feed nozzles } & \cdots & 5 \text { and } 9\end{array}$

Each test requires about 30 hours of steady state running which means that the total data collecting hours for Test Series 1 will be about 500. To allow for down-time and aborted runs, at least two months should be allowed to complete Test Series 1. Time will be allocated for Reliability Trials to prove the Research Instrumentation prior to commencing Test Series 1 :

As Hot Commissioning at the time of writing has not been completed the plant operating envelope remains to be determined. Once determined it may be necessary to modify the planned experiments to match the plant's capability. 
1. Introduction and background.

2. Test Series 1 objectives.

3. Data collection instrumentation requirements.

4. Test logic and run conditions.

5. Test sequencing and duration.

6. Impact of plant capabilities upon Test Series 1.

1. Huel teedstocks. 
Figure 1: "Good Fluidisation" Lines used in Test Series 1

Table 1: Phase 1 Research Programme as defined in May' 79 Baseline document.

Table 2: Test Series 1 as outlined in May '79 Baseline document.

Table 3: Changes made to May 79 Baseline Test Series 1 objectives during development of current objectives.

Table 4: Primary variables influencing combustion and sulfpur retention efficiencies.

Table 5: Experiments for Test Series 1 on the high velocity "good fluidisation" line including original design conditions.

Table 6: Experiments for Test Series $1 \mathrm{cn}$ medium velocity "good fluidisation" line.

Table 7: Experiments for Test Series 1 on low velocity "good fluidisation" line including CURL Link Test condition.

Table 8: Matrix of Test Series 1 experiments. 


\title{
ACKNOWLEDGEMENTS
}

The Grimethorpe Experimental Facility is intended to carry out research into pressurised fluidised bed combustion on behalf of the three Sponsors.

The Governments of the federal kepuulle uf Germany, the Unitod States of America and the United Kingdom, under the auspices of the International Energy Acency, have agreed to share equally between them the costs of building and operating the Facility.

The Project is funded by the Sponsoring countrles Lhovigh the following agencies.

\author{
F'KG Kernfusschungsanlage Juliah $\mathrm{GmbH}$ \\ UK Department of Energy \\ US Department of Energy
}

The Facility has been built on a site adjoining a power station at the National Coal Board's Grimethorpe Colliery, South Yorkshire, Enyland. 
The overall programme content and the technical objectives of the Phase 1 Research Programme have been set out in earlier documents and submissions to the Technical committee. The draft document "phase 1 Research Programme: Baseline and Modified Option Cases" (I) was produced in May 1979 and discussed at subsequent Technical Committee Meetings; in the remainder of the text this document is referred to as the May 79 Baseline. It was agreed that the Baseline Case would be followed rather than the lesser Modified Option Cases. Included in the May ' 79 Baseline were the overall objectives of the experimental programme, a short summary of which are presented in Table 1 together with estimated data collection hours for each of the four test series. The May' 79 Baseline also included the requirements for additional plant instrumentation, termed Research Instrumentation, and a preliminary description of the experimental tests although all the actual run conditions were not defined. The key points of the Test Series 1 programme, as then defined, are presented briefly in Table 2. The objectives in the May 79 Baseline form the basts from which the currently proposed objectives, presented in section 2, have evolved. The main changes to the May' 79 Baseline objectives are noted in Table 3 along with short explanations for the changes.

The development of the Test Series 1 programme has been influenced successively by:-

- Results from CURL Link Test (April 1980)

- Cold commissioning results from the Grimethorpe plant.

- Early hot commissioning results (November/December 1980).

- Overall project schedule.

- Views expressed by and through the Technical Committee.

At the January 1981 Technical Committee Meeting the current status of the test programme was presented (2). The presentation outlined the work completed, that in progress and that currently outstanding in proving the Grimethorpe plant as a test facility. It was considered that given the uncertainties regarding the plant's capabilities at the stage of commissioning reached, it was not possible to produce a final test plan in which all the proposed test conditions could be achieved. Three alternative scenarios were presented that considered the effects of varying degrees of commissioning success together with lengthy installation periods for the Research Instrumentation and Tube Bank ' $C$ '. Although these scenarios were discussed it was agreed that any decision would require further information and that the project should obtain that information by continuing with its proposed hot commissioning programme. The Technical Committee members expressed the view that a substantial amount of technical data should be obtained at the earliest time and that data obtained with Tube Bank 'A' remained of interest.

The Technical Committee considered that it was hampered in reyiewing longer term plans by the absence of a test plan for Test Series 1 . It was, therefore, agreed that the Operating Agent would produce and circulate the first test plan document, the Outline Test Plan, for review by the Technical Committee as soon as possible. It was accepted that an outline Test plan produced at this stage of commissioning could not adequately take into account the uncertainties concerning the plant's test capability.

(1) Document Number IEA/FBC/2705.79/EC/DS

(2) Document Number GEF/TC/P/81/2 
This document presents the current objectives for Test Series 1 together with the programme of operating conditions and research instrumentation to satisfy these objectives and goes onto preliminary considerations of test sequencing and duration. If further hot commissioning leads to substantial changes in test run conditions then a revised Outline Test Plan will be circulated to the Technical Committee prior to preparing the detailed Test plan. The documents to be prepared by the Operating Agent specifically concerned with Test Series 1 are identified in the Technology Transfer plan; these documents include:-

- Outline Test Plan.

- Test Plan.

- Test Series Run Reports.

- Report for Test Results.

. Kepnrt. of Plalit Operations During Test.

Adullivially it is anticipated that several short reports, not yet identified, will be produced from Test Series Une 1nformaliuid. These reports were termed Incident Reports and Materials Reports in the Technology Transfer plan. All reports will be sent to the Technical Cormittee members for review.

\section{TEST SERIES ONE OBJECTIVES}

The technical objectives currently proposed for Test Series 1 are set out below;

1. To obtain performance data and to determine the effect of process variahl.e.s upon;

a) combustion and sulphur retention efficiencies,

b) elutriation and particle breakdown characteristics,

c) in-bed heat transfer rates,

d) cyclone collection efficiencies,

e) $\mathrm{NO}_{x}$ and alkali emissions.

The data will be obtained along "good fluidisation" lines related to high, mcdium and low fluirising velocities.

2. To run at similar conditions to those of the CURL Link Test to aggcss the effect of process scale-up.

3. To test the validity of the proposed Battcock-Pillai relationship between mean hed particle size and fluidising conditions.

4. To check the reproducibility of data by comparing results from runs at similar conditions.

5. To determine the influence upon sombustor performance of increasing fuel feed nozzles from 5 to 9. 
6. To obtain data at similar operating conditions to compare the effects of 'Tube Bank ' $A$ ' and Tube Bank ' $C$ ' configurations upon combustor performance.

7. To start the materials corrosion test programme.

3. DATA COLLECTION INSTRUMENTATION REQOIREMENTS.

The combustor performance and studies listed in the objectives will require mass and energy envelopes to be drawn around the combustor with good closures for confidence to be placed in the results. Although the main plant contains extensive process instrumentation additional instrumentation requirements, termed Research Instrumentation, were identified in the May 79 Baseline document as being necessary to measure combustor performance characteristics and effluxes. The Research Instrumentation installation is currently in progress and will continue during Hot Commissioning shut-down periods. Several simple slurry sampling arrangements are installed and currently being commissioned.

The control envelope for the combustor mass balance is drawn to include the input streams and the output streams from the bed and the primary cyclones. The combustor input flowrates of air, coal, dolomite and purge nitrogen are continuously measured using existing process instrumentation. The additional measurements necessary to complete the mass balance are obtained with the following instrumentation; an asterisk (*) denotes the item is installed.

1. Combustor solids feed sampling system ( $*$ ).

2. Bed ash removal from combustor discharge legs.

3. Horizontally traversing Acurex dust probes in the vertical ducts downstream of three primary cyclones.

4. Horizontal fixed dust sampling probe(s) in the vertical duct downstream of the fourth primary cyclone when in use.

5. Primary cyclone underflow solids sampling on two of the cyclones,

6. Fixed dust sampling probe in the common horizontal duct between the secondary cyclones and the main heat exchanger.

7. Fixed aerosol sampling probe in the common horizontal duct between the secondary cyclones and the main heat exchanger.

8. Gas analysis of off-gas after primary cyclones (*).

9. Slurry sampling systems for cross-cherking snlid discharge rates and composition $(*):-$

- bed ash slurry after blowdown vessel.

- primary cyclone slurry after blowdown yessel.

- secondary cyclone slurry after blowdown vessel. 
Two additional items of instrumentation are required to obtain in-bed characteristics and these are:-

1. In-bed heat transfer probes.

2. In-bed corrosion probes.

\section{TEST LOGIC AND RUN CONDITIONS.}

An analysis of published experimental data has identified the primary process variables influencing combustion and sulphur retention efficiencies (see Table 4). These dependents have been used to aid the formulation of the experimental programme for Test Series 1. The objectives presented in section 2 will be fulfilled as a consequence of following this programme.

The experiments will be carried out aleng three different "good fluidisation" lines i.e. a set of fluidising conditions for which the mean bed particle size is expected to remain constant. Such a procodure is desirable as it eliminates delays incurred in waiting for the bed to reach particle size equilibrium. The "good fluidisation" lines used are presented diagrammatically in Figure 1.

Test Sub-Series

A. High Velocity Tube Bank 'A'

design conditions

B. Medium Velocity

Optimum conditions

for Tube Bank ' $A$ '

C. Low Velocity

Tube Bank ' $C$ '

design conditions,

inrluting CURL

Lilik Teat

$$
\begin{aligned}
& \text { Velocity range } \\
& \mathrm{m} / \mathrm{s} \text { (fps) }
\end{aligned}
$$

$$
\begin{gathered}
2.4 \text { to } 2.5 \\
(7.9) \quad(8.2)
\end{gathered}
$$$$
1.8 \text { to } 2.3
$$$$
\text { (5.9) (7.6) }
$$

1.6 to 2.0

(5.3) (6.6)
Number of Tests

4

7

6
Data Collection hours, approx.
120

210

180

In all three sub-serits the porition on the "good fluidisation" line and the mean fluidising velocity are both determined by the air mass flow rate, pressure and mean bed temperature; these three variables are, therefore, Lulergependcnt. The prncess variables influencing combustion efficiency are mean bed temperature, excess air level and gas residence time in the bwi the last two parameters cannot be varied independently. Once having decided the excess air level this determines the rate of heat release and the extent of tube bank immersion necessary to control the bed temperature. It follows that defining the excess air level automatically establishes the bed height and vice versa which in turn determincs the gas residence time in the bed (bed height divided by mean gas velocity). Fixing the position on the "good fluidisation" line and one other variable, either excess air level on bed height, defines all three process variables which influence combustion efficiency. 
The high velocity line experiments are presented in Table 5 . The first three experiments investigate the effect of three mean bed temperatures, 800,850 and $900^{\circ} \mathrm{C}$, upon combustion efficiency. The other variables are deliberately adjusted either to match the "good fluidisation" relationship or adjust automatically to match process requirements. In the fourth experiment the effect of the number of fuel feed nozzles upon combustor performance is investigated. Runs $1 \mathrm{~A}-1$ and $1 \mathrm{~A}-4$ are at the original design datum conditions for Tube Bank 'A' albeit at a higher excess air level than originally expected. These excess air levels, 55 to $75 \%$, are just outside the range of values, 25 to $50 \%$ which is opined to be the optimum for the supercharged boiler cycle.

The medium velocity line experiments are presented in Table 6 . These experiments have been defined by the air mass flow rate necessary to enable the combustor to operate at $10 \mathrm{bar}, 35 \%$ excess air and a mean bed temperature of $850^{\circ} \mathrm{C}$ with Tube Bank ' $\mathrm{A}$ ' fully immersed. These conditions are regarded as the most appropriate for operation of Tube Bank ' $A$ ' in the light of current thinking on optimum excess air values for the supercharged boiler cycle. There are four experiments similar to those for the high velocity sub-series with three additional experiments. The effect of excess air level upon combustion efficiency is investigated; by increasing the excess air level the heat release rate is reduced and so the bed height drops. The effect of operating at a lower pressure upon combustor characteristics is investigated; the mean gas velocity is increased but the air mass rate is reduced to comply with "good fluidisation" requirements so the rate of heat release and hence the bed height (for a fixed excess air level) are both reduced. The effect of $\mathrm{Ca} / \mathrm{s}$ ratio upon sulphur retention is also investigated.

The low velocity line experiments are presented in Table 7 and investigate similar variables to the medium velocity sub-series. There is, however, no run with a mean bed temperature of $900^{\circ} \mathrm{C}$ as the tests are all with reduced bed heights analogous to turn-down conditions which would not be carried out at such a high temperature. The combustion efficiency at these conditions is expected to be lower than is considered acceptable but the performance data enables important comparisons to be made with the CURL Link Test and tests from Test Series 2 with Tube Bank ' $C$ '.

The relationship of each of the experiments within these three sub-series to the overall objectives of Test Series 1 is presented in Table 8 . A consequence of the restricted freedom to alter variables independently and of limiting the range of excess air values to those of general commercial interest is that the combustion efficiencies are not expected to vary appreciably. This may make it difficult to establish performance trends with any confidence. In such cases it may prove necessary to impose known relationships upon the data and then test their goodness of fit. It should be noted that in defining the experimental conditions for each of the three "good fluidisation lines" the validity of the Battcock-Pillai correlation has been assumed. The correlation will, however, still be checked experimentally.

5. TEST SEQUENCING AND DURATION.

Hot Commissioning will be followed by the installation of the Besearch Instrumentation required for Test Series 1. Instrumentation commissioning would lead into the Reliability Running Trials where the objectiyes would be to prove the adequacy of the full plant instrumentation and the test procedures to be employed. These objectives would be realised by operating the plant for periods of sufficient length. to allow measurements for heat and mass balancing to be completed. This stage of the work should be completed satisfactorily before proceeding to Test Series 1 . 
Following the completion of the Reliability Running Trials then Test Series 1 will commence with the first test sub-series. Neither the sequence of the three test sub-series, nor the sequence within the sub-series, has yet been finalised. Views expressed to the operating Agent to date suggest that priority should be given to; the High Velocity data in sub-series lA; the data from a fully submerged tube bank in sub-series $1 A$ and part of $1 B$; and the Leatherhead Link Test comparison, run 1C-1. In addition it has been suggested that data obtained with the tube bank only partly immersed are of lesser value ( 3 out of 7 tests in sub-series $1 \mathrm{~B}$, and 5 out of 6 tests in 1C). Clearly all these views cannot be satisfied. There are several factors influencing the order of the tests, two important but somewhat contradictory factors are:-

- Given that the plant may fail part way through the programme, then priority should be given to the most important tests. However, all three sub-series contain data which is considered important. Further division of test sub-series would increase the number of changes between "good fluidisation" lines,

- Given that tho gas velosity through the ryelone systew slould be kept within a range that satisfies both good cyclone collection efficiencies and ductwork erosion considerations then the numbers of cyclone trains in line should be changed between sub-series. As four cyclones are currently installed the order to minimise plant modification would be: Test Sub-series IA High Velocity Data 4 cyclones Test Sub-series IC Medium Velocity Data

$2 / 3$ cyclones Low Velocity Data

2 cyclones

Whatever sequence is adopted it is intended to carry out Test series $1 \mathrm{~A}$ in one run interval, but to split both Test series $1 B$ and $1 C$ into two run intervals each. Splitting the tests in this manner is considered desirable in the early stages of Phase 1 experimentation as 1 t alluws lie plant and particularly the combustor internals to be inspected trequenty and component deterioration identified and rectified if necessary. For example, the scal modifioation between the distrihutinr and water walls would benefit from such inspections.

Each test period is expected to be of about 30 hours duration to enable the required amount of data to be collected, the dust and solid sampling times having the major influence. The total number of experluental data collection hours for the planned seventeen tests in series 1 is, therefore, approximately 500. It was envisaged that during the early stages of the Phase 1 Programme that the rat1o of data cullecilisy to coal burning operating hours would be $1: 2$, hence some 1000 hours (or 40 days) should be allowed for operation. provided that there are no major breakdowns it. is considered that a minimum of two months should be allowed for Test Series 1. Experience with plant operation during further hot commissioning will better define these estimates.

6. IMPACT OF PLANT CAPABILITIEE UPON TEST SERIES 1.

The hot commissioning of the Grimethorpe plant still awaits completion at the time of preparation of the Outline Test Plan. The main plant's present capability as an experimental unit for test operation is, therefore, not fully defined. After further hot commissioning in February/March 1981 when the operating envelope is better defined, it may be necessary to substitute certain of the experimental runs for others at different operating conditions; this also may lead to the revision of the test series objectives. 
During hot commissioning in November/December 1980 several potential problem areas that could influence the test conditions were identified and were discussed at the January Technical Committee Meeting. Two of the potential problem areas were:-

- Presence of vertical temperature gradients over the height of the Tube Bank. Under certain operating conditicns these may lead to unacceptable high temperatures below the tube bank.

- Bed material removal is still to be demonstrated. Close bed level control is especially needed for experiments where less than full depth bed operation is planned.

It is intended to investigate the impacts of such potential constraints during the hot commissioning period so that by its end Test Series 1 Test Plan can be finalised.

\section{FUEL FEEDSTOCKS}

Nostell part-cleaned coal and Whitwell dolomite were used for the CURL Link Test run and the same fuels will be used for Test Series 1. Typical chemical analyses are presented in Table 9. It is likely that a coarser size distribution will be used for sub-series $I A$ than sub-series $I B$ and $I C$. 
FIGURE 1. "GOOD FLUIDISATION" LINES USED IN TEST SERIES 1. SHOWN FOR CONDITIONS WITH A BED TEMPERATURE OF $850^{\circ} \mathrm{C}$

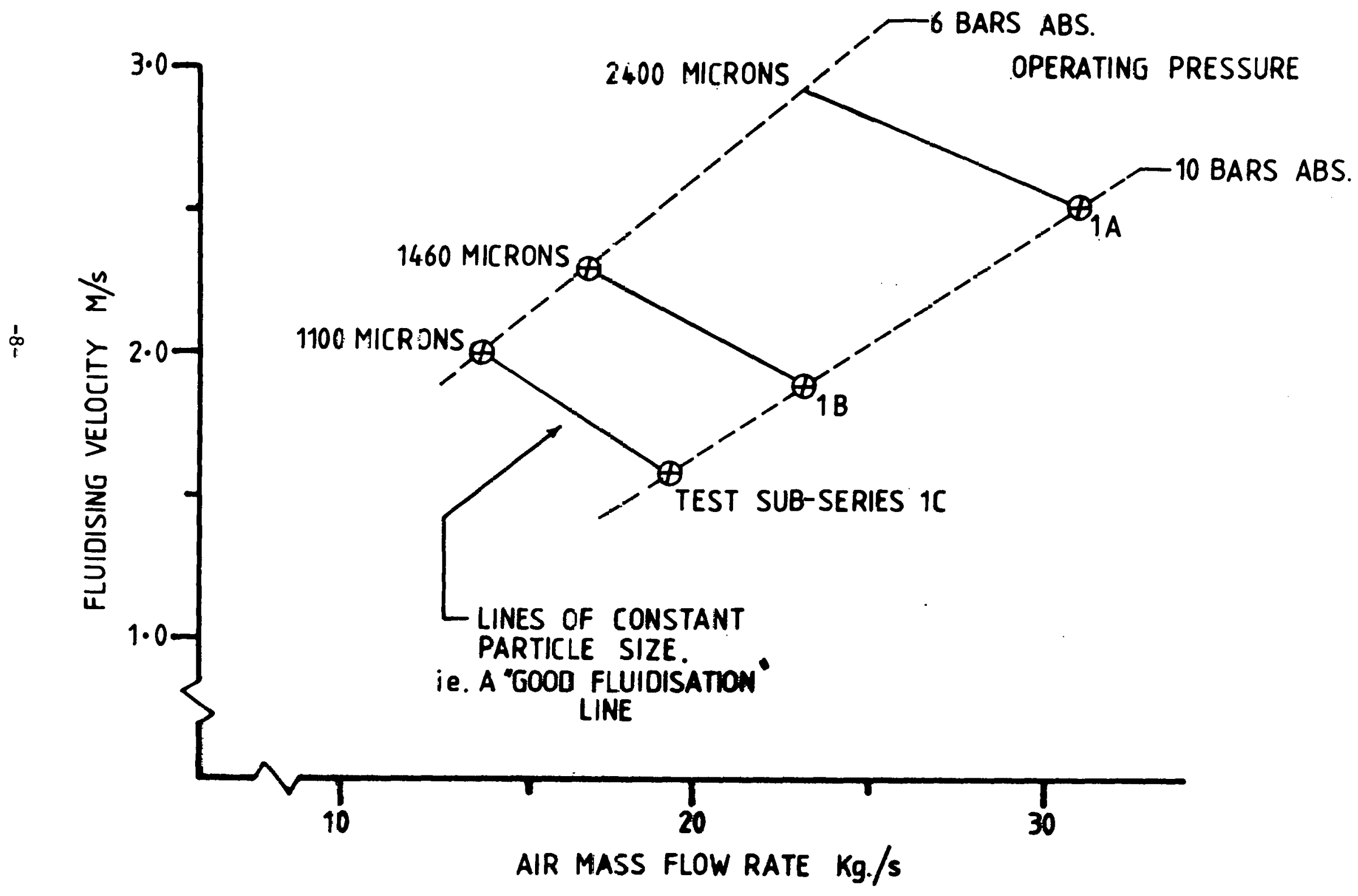


TEST SERIES 1.1

HIGH VELOCITY TUBE BUNDLE (ORIGINAL INSTALLATION) AT ORIGINAL DATUM CONDITIONS
1. COMBUSTOR PERFORMANCE

2. RELIABILITY, ADEQUACY, OPERABILITY OF INSTRUMENTATION .

3. REPRODUCIBILI'IY OF DATA.

4. EFFECT OF MAIN PROCESS VARIABLES

TEST SERIES 1.2

HIGH VELOCITY TUBE BUNDLE OPERATED WITH REDUCED BED LEVEL TO ACCOMMODATE LOWER VELOCITY CONDITIONS

1. COMPARATIVE EFFECT OF MAIN PROCESS VARIABLES AT LOWER VELOCITY

2. DESIGN VERIFICATION DATA FOR NEW TUBE BANK

250

TEST SERIES 2

LOW VELOCITY TUBE BUNDLE TERTIARY FILTER CASCADE (S) INSTALLED

1. COMPARATIVE TESTS WITH ALTERNATIVE UK, US AND FRG COALS

2. PERFORMANCE OF CLEAN-UP DEVICES/CHARACTERISATION OF OFF-GAS

3. DEPOSITION, FOULING, EROSION OF CASCADE

TEST SERIES 3

TURN DOWN, DYNAMIC RESPONSE

NOT DEFINED

400

TEST SERIES 4

MECHANICAL MODIFICATION, SUCH AS REDUCED NUMBER OF FUEL FEED NOZ7.T.F.S 30 OR CHANGE'L POSITION OF AIR DISTRIBUTOR, ETC. 
TEST SERIES I AS OUTLINED IN MAY 79 BASELINE DOCUMENT

- DETERMINE EFFECT OF PROCESS VARIABLES UPON:

- COMBUSTION AND SULPHUR RETENTION EFFICIENCIES

- ELUTRIATION AND ATTRITION CHARACTERISTICS

- IN-BED HEAT TRANSFER RATES

- CYCLONE COLLECTION EFFICIENCIES

- NO $x$ EMISSIONS

- LEATHERHEAD LINK TEST COMPARIISON

- EXPERIMENTAL TESTING TO DEMONSTRATE:-

- RELIABILITY, ADEQUACY AND OPERABILITY OF INSTRUMENTATION

- REPRODUCIBILITY OF DATA

- TESTING WITH SECOND UK COAL

- 500 EXPERIMENTAL DATA GATHERING HOURS

- 50:50 DIVISION BETWEEN HIGH ANT LOW VELOCITY RAMPLINE CONDITIONS. 
TABLE 3

CHANGES MADE TO MAY 179 BASELINE TEST SERIES 1 OBJECTIVES

DURING DEVELOPMENT OF CURRENT OBJECTIVES

1. Testing the influence of number of fuel feed nozzles upon combustor performance has been brought forward from Test Series 4 into Test Series 1.

This measure was carried out as a response to opinions expressed by potential users of PFBC and also due to possible limitations on Petrocarb turndown.

2. Testing the validity of the proposed Battcock-Pillai relationship between mean bed particle size and fluidising conditions has been introduced.

This measure was considered desirable as the relationship if yalid will prove of value to fluidised bed combustion development in terms of improved control.

3. Reliability and operability of instrumentation and reproducibility of data have in part been brought forward to the Reliability Running Trials.

This measure was considered to be beneficial from an experimental point of view in gaining confidence in the unit as a test plant prior to Test Series 1.

4. Testing effect of process variables upon alkali emissions.

This measure was considered desirable to obtain alkali measurements when the rig was operating at coal feed rates higher than Tube Bank ' $C$ ' may be capable of.

5. Deleted operation with alternate UK coal of a lower ash fusion temperature.

It was considered that the temperature gradients experienced on the Link Test and during initial hot commissioning could result in temperatures close to the fusion point being experienced so making testing potentially problematic. Further, it was considered that work to compare the combustor performance between Tube Bank ' $A$ ' and Tube Bank ' $C$ ' should be carried out with the same coal.

6. Addition of testing to compare combustor performance between Tube Banks ' $\mathrm{A}$ ' and ' $\mathrm{C}$ '.

At the time of the May 179 Baseline preparation it was envisaged that Tube Bank ' $C$ ' wuld bo simply a reduced surface area version of Tube Bank ' $A$ ', however, ' $C$ ' has now been designed to have a more open structure than ' $A$ '. 
PRIMARY VARIABIES INFLUENCING COMBUSTION AND

SULPHUR RETENTION EFFICIENCIES

PERFORMANCE PARAMETER

Combustion efficiency
PRIMARY VARIABIES

Coal type, gas residence time in bed, excess air, bed temperature and number of fuel feed nozzles per unit area.

Dolomile type, dolomile size, Co/s molar ratio, gas residence time in hnd and number of fuel feed nozzles per unit ared.

Sulphur retention (2)

(1) Pressure is considered to have only a secondary effect upon combustion efficiency over the range of pressures employed in Test Series 1 . This consideration has been assumed to be correct but will be checked during data analysis.

(2) Temperature can also influence sulphur retention efficiency but not over the range of temperatures expected to be investigated during Test Series 1. Pressure may also have an effect but this is considered to be of secondary importance over the range of pressures to be investigated. 
TABLE 5

EXPERIMENTS FOR TEST SERIES 1 ON THE HIGH VEIOCITY "GOOD FLUIDISATION" LINE INCLUDING ORIGINAL DESIGN CONDITIONS.

\begin{tabular}{|c|c|c|c|c|c|c|c|c|}
\hline RUN & $\begin{array}{l}\text { MEAN BED } \\
\text { TEMP. }{ }^{C} \mathrm{C}\end{array}$ & $\begin{array}{l}\text { FUEL FEED } \\
\text { NOZZIES, - }\end{array}$ & $\begin{array}{l}\mathrm{Ca} / \mathrm{S} \text { MOLAR } \\
\mathrm{RATIO},-\end{array}$ & $\begin{array}{l}\text { PRESSURE } \\
\text { BAR ABS }\end{array}$ & $\begin{array}{c}\text { AIR RATE } \\
\mathrm{KG} / \mathrm{S}\end{array}$ & $\begin{array}{l}\text { MEAN GAS } \\
\text { VEL. ,M/S }\end{array}$ & $\begin{array}{c}\text { EXCESS AIR } \\
\varangle\end{array}$ & $\begin{array}{c}\text { BED DEPTH } \\
\mathrm{M}^{*}\end{array}$ \\
\hline $1 A-1 *$ & 850 & 5 & 2.6 & 10 & 31 & 2.5 & a.f. (65) & full \\
\hline $1 A-2$ & 800 & 5 & 2.6 & 10 & 32 & 2.4 & a.f. (72) & full \\
\hline $1 A-3$ & 900 & 5 & 2.6 & 10 & 30 & 2.5 & a.f. (56) & full \\
\hline $1 A-4$ & 850 & 9 & 2.6 & 10 & 31 & 2.5 & a.f. (65) & full \\
\hline
\end{tabular}

* An original design condition. This run defines the "good Eluidisation" line.

a.f. as found, ( ) bracketted values are estimates 
ThBLE 6

EXPERIMENTS FOR TEST SERIES 1 ON THE MEDIUM VELOCITY

"GODD FLUIDISATION" LINE

RUN

MEAN BED

FUEL FEED

$\mathrm{Ca} / \mathrm{S}$ MOLAR

PR SSSURE AIR RATE

MEAV GAS TEMP. ${ }^{{ }^{C} \mathrm{C}}$ NOEZLES - RATIO, -

BAR ABS

$\mathrm{KG} / \mathrm{S}$

VEL. , $\mathrm{W} / \vec{S}$

EXCESS AIR BED DEPTH

$1 \mathrm{~B}-1 \quad \&$
$1 \mathrm{~B}-1 \mathrm{a}$

850

1.8

10

$23 *$

1.9

35

fu11

1B-2

850

2.6

10

23

$-.9$

70

a.f. (2.9)

$18-3$

805

2.6

10

24

1.8

a.f. (40)

full

$1 B-4$

900

2.6

10

22

1.9

35

a.f. (3.1)

$1 B-5$

850

2.6

10

23

1.9

35

full

$1 B-6$

850

2.6

10

23

1.9

35

full

$1 B-7$

850

2.6

6

17

2.3

35

a.f. (2.7)

* This is an estimicted value of the air mass fiow raze zecessary to ənatle the combistor to operate at 10 bar, $35 \%$ exioss air and a near. Jed temperature of $850^{\circ} \mathrm{C}$ with Tube Bant: 'A " Fully submerged. This value is used to define the "good fluidisat: $2 n$ " line to which all the other conditions are related. The aztual value should be deternined experimentally and the sther conditions redefined accordingly. If possible run 1B-1. will be carried out as part of jie Reliability Trial and duplicated as run 1B-la to oktain a measur of data reproducibility.

(1) brazketted values are estimates. a.f. as found 
TABLE 7

EXPERIMEINTS FOR TEST SERIES 1 ON THE LOW VELOCITY

"GOOD FLUIDISATION" LINE INCLUDING CURL LINK TEST CONDITION.

\begin{tabular}{|c|c|c|c|c|c|c|c|c|}
\hline RUN & $\begin{array}{l}\text { MEAN BED } \\
\text { EEMP. , }{ }^{\mathrm{C}}\end{array}$ & $\begin{array}{l}\text { FUEL FEED } \\
\text { NOZZLES - }\end{array}$ & $\begin{array}{l}\text { Ca/S MOLAR } \\
\text { RATIO, - }\end{array}$ & $\begin{array}{l}\text { PRESSURE } \\
\text { BAR ABS }\end{array}$ & $\begin{array}{c}\text { AIR RATE } \\
\mathrm{KG} / \mathrm{S}\end{array}$ & $\begin{array}{l}\text { MEAN GAS } \\
\text { VEL . M/S }\end{array}$ & $\underset{q}{\text { EXCESS AIR }}$ & ${ }_{M}^{B E D ~ D E P T H}$ \\
\hline $1 C-1$ * & 850 & 9 & 1.8 & 6 & 14 & 2.0 & 35 & a.f. (1.7) \\
\hline $1 C-2$ & 850 & 5 & 1.8 & 10 & 19 & 1.6 & 35 & $a, f . \quad(2.3)$ \\
\hline $1 c-3$ & 850 & 5 & 2.6 & 10 & 19 & 1.6 & 35 & a.f. (2.3) \\
\hline $1 C-4$ & 850 & 5 & 2.6 & 10 & 19. & 1.6 & 70 & a.f. $(2.0)$ \\
\hline $1 C-5$ & 800 & 5 & 2.6 & 10 & 19 & 1.6 & 35 & $a, f . \quad(2.5)$ \\
\hline $1 C-6$ & 850 & 9 & 2.6 & 10 & 19 & 1.6 & 35 & a.f. (2.3) \\
\hline
\end{tabular}

a.f. as found, ( ) bracketted values are estimates. 


\section{TABLE 8}

MATRIX OF TEST SERIES 1 EXPERIMENTS

TEST RUNS

$1 C-1$

1B-1, $1 \mathrm{~B}-7,1 \mathrm{C}-1$ and $1 \mathrm{C}-2$

IB $1,1 \mathrm{~B}-3,1 \mathrm{C}=2$ and $1 \mathrm{r}:-4$

$18-1, \quad 18=\%, \quad 11:-3$ and $1 C-3$

$1 B-1,1 B-3,1 B-4$,

1.C- 3 and $1 C-5$

$1 A-1,1 A-4,1 B-5$, $1 B-6,1 C-3$ and $1 C-6$

$1 B-1$ and $1 B-1 a$

1A, IB and IC Series

$1 A-1$ to $1 A-4$

IC Series

\section{TO STUDY INFLUENCE OF}

Scale-up upon combustion parameters determined in the CURL Link Test.

Residence time on combustion and sulphur retention efficiences.

Excess air level on combustion efticiency

CQ 3 Ratio on mlphur retention efficiency

Bed Temperature on combustion efficiency

Number of feed nozzles on combustion and sulphur

retention efficiency and bed temperature stability

Bepeat experiments upon reproducibility of data

Varying conditions upon the "good fluidisation" hypothesis, elulriation and particlc hroakdown characteristics, in-bed heat transfer rates; cyclone collection efficiencies and $\mathrm{NO}_{x}$ and alkall emissions.

original design conditions upon combustor performance parameters.

'l'ube bank conliguration upon combuctor performance. by romparison with data obtained at similar conditions with. Tube Bank ' $\mathrm{C}$ ' 
I'YPICAL CHEMICAL ANALYSES OF THE COAL AND DOLOMITE

FEEDSTOCKS TO BE USED IN TEST SERIES 1

NOSTELL COAL

\begin{tabular}{lcc} 
Moisture & $\ldots$ & 4.8 \\
Ash & $\ldots$ & 22.0 \\
Volatile matter & $\ldots$ & 29.4 \\
Total sulphur & $\ldots$ & 1.68 \\
Chlorine & $\ldots$ & 0.06 \\
Hydrogen & $\ldots$ & 3.97 \\
Carbon & $\ldots$ & 59.2 \\
Nitrogen & $\ldots$ & 1.37 \\
$\mathrm{CO}_{2}$ & $\ldots$ & 0.05 \\
Oxygen - by difference on a & \\
\multicolumn{2}{c}{ d.m.m.f. basis } \\
Calorific value & $\ldots$ & 7.29 \\
Swelling number & $\ldots$ & $24360 \mathrm{KJ} / \mathrm{Kg}$ \\
\end{tabular}

ASH FUSION

Initial Deformation

Hemispherical Deformation

Fusion
BEDUCING ATMOSPHERE

$1150^{\circ} \mathrm{C}$

$1390^{\circ} \mathrm{C}$

$>\quad 1400^{\circ} \mathrm{C}$
OXIDISING ATMOSPHERE

$>1400^{\circ} \mathrm{C}$

\section{WHITWELL DOLOMITE}

$\begin{array}{lcc}\text { Potassium as } \mathrm{K}_{2} \mathrm{O} & \ldots & 0.01 \\ \text { Sodium as } \mathrm{Na}_{2} \mathrm{O} & \ldots & 0.03 \\ \text { Calcium as CaO } & \ldots & 27.0 \\ \text { Magnesium as Mgo } & \ldots & 22.5 \\ \text { Iron as } \mathrm{Fe}_{2} \mathrm{O}_{3} & \ldots & 0.5 \\ \text { Aluminium as } \mathrm{Al}_{2} \mathrm{O}_{3} & \ldots & 0.4 \\ \text { Silicon as } \mathrm{SiO}_{2} & \ldots & 1.8 \\ \text { Sulphur as } \mathrm{SO}_{3} & \ldots & 0.1 \\ \text { Carbon as } \mathrm{CO}_{2} & \ldots & 47.2\end{array}$


